\title{
TRIP600 ACÉL LÉZERVÁGÁSA KÜLÖNBÖZŐ MUNKAGÁZOK ALKALMAZÁSÁVAL
}

\section{THE TRIP600 STEEL LASER CUTTINGS IN CASE OF DIFFERENT ASSISTING GASES}

\author{
Tuloki Szilárd ${ }^{1}$, Pinke Péter $^{2}$ \\ ÓbudaiEgyetem, Bánki Donát Gépész és Biztonságtechnikai Mérnöki Kar, H-1034 \\ Magyarország Budapest, Bécsi út 96/B; Telefon / Fax: +12-345-6789123 \\ ${ }^{1}$ tuszilard@gmail.com \\ 2 pinke.peter@bgk.uni-obuda.hu
}

\begin{abstract}
This paper presents the experimental investigation of TRIP600 steel cutting with a TruLaser Cell 7020/Trudisk 4001 laser machine, and using different cutting parameters (assist gases, output power, single / double process). We observed the effects of the parameters on the kerf and hardness of the HAZ. Cutting with laser beam is today very popular and promising. One of most used process in the automotive industry too. With this technology we can archive low material consumption, shorter processing times and great accuracy of the product. However, in order to exploit the advantages of this technology, it is necessary to optimize each processed material relevant influential parameters. Our goal was to find the optimal cutting parameters for the TRIP 600 steel.
\end{abstract}

Keywords: laser cutting, hardness, HAZ, TRIP 600 steel.

\section{Összefoglalás}

Ebben a cikkben TRIP 600 acélon végrehajtott lézervágási kísérletsorozat eredményeit mutatjuk be, amelyet TruLaser Cell 7020 / Trudisk 4001 lézergép segítségével különböző vágási paraméterek (munkagáz, teljesítmény, közvetlen/kombinált vágás) mellett végeztünk el. A lézervágás hatását a vágási rés mérete és a hőhatásövezeti keménység alapján értékeltük. Napjainkban a lézervágás nagyon elterjedt és széles körben alkalmazott technológia az autóiparban is. Ezzel a technológiával kis anyagveszteség és nagy pontosság mellett rövid feldolgozási idő érhető el. A technológiai elönyöket a paraméterek optimális beállítása biztosítja. Célunk az volt, hogy megtaláljuk az optimális vágási paramétereket a TRIP 600 acél lézervágásához.

Kulcsszavak: lézervágás, keménység, höhatásövezet, TRIP600 acél.

\section{Bevezetés}

Napjainkban a termikus vágási eljárások rendkívül elterjedtek az ipari gyakorlatban. A lézervágás széles körben alkalmazott eljárás az autóipari karosszéria-technológia területén [1], [2]. Ezzel a technológiával rövid vágási idő érhető el kis anyagveszteség és nagy vágási pontosság mellett. A technológia előnyeit a vágási paraméterek optimális kiválasztása biztositja. Elsődleges hatású [3]: a védőgáz fajtája és nyomása, a lézer teljesítménye, a vágás sebessége és a sugár fókuszpozíciója. Dolgozatunkban, egy kísérletsorozat részeként [4] TRIP 600 acélon lézeres résvágással vizsgáltuk három munkagáz $\left(\mathrm{N}_{2}, \mathrm{Ar}, \mathrm{O}_{2}\right)$ hatását a vágási rés méretére és a hőhatásövezet keménységére. 


\section{TRIP acélok (Transformation Induced Plasticity)}

A TRIP acélok, azaz az átalakulással előidézett képlékenységgel rendelkező acélok, jó alakíthatósággal és kellően nagy szilárdsággal rendelkeznek. Szövetük többfázisú: ferritből, bénitből, martenzitből valamint maradék ausztenitből áll (1.ábra) [5]. TRIP acél jellemző szövetszerkezetét a 2. ábra mutatja [6].

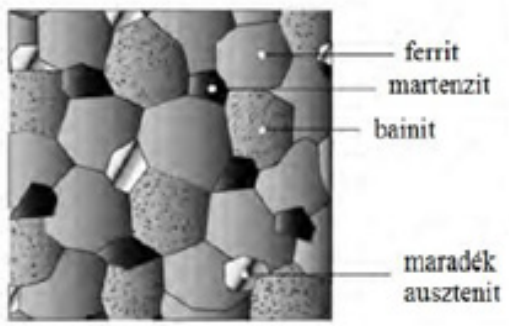

1. ábra. TRIP acél szövetszerkezetének vázlatos ábrázolása [5]

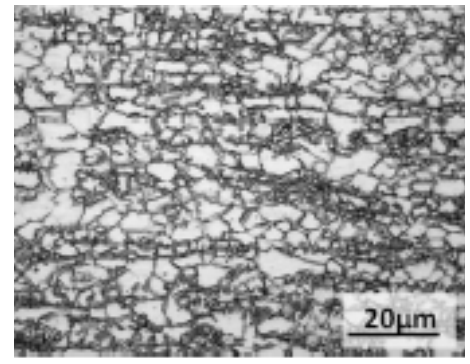

2. ábra. TRIP acél mikroszerkezete [6]

A TRIP 600 acél és további két nagyszilárdságú acél (DP 600, HSLA 450 szakítódiagramját a 3. ábra vázolja [5]. Látható, hogy a TRIP acél rendelkezik a legjobb képlékenységgel a folyáshatár feszültség és a szakítószilárdság tartományban. A TRIP acélok nagy energia-elnyelö képességgel bírnak, ez megfelelően illeszkedik az autóipari és biztonsági alkatrészekkel szemben támasztott követelményekhez, például kereszttartók, oszloperősítések, hosszgerendák, küszöbök, lökhárítóerősítések esetében.

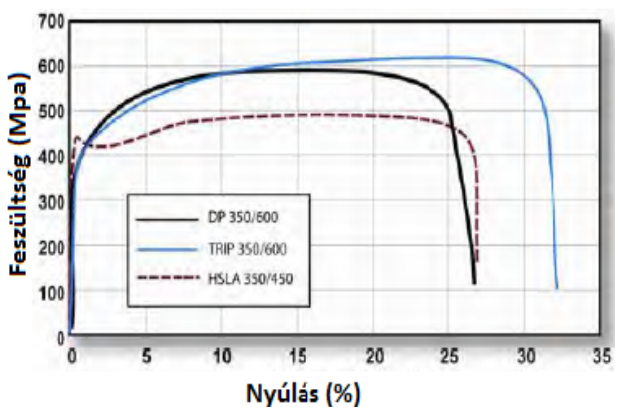

3. ábra. TRIP 600, DP 600 és HSLA 450 acélok jellemzö nyúlás és feszültség értékei [5]

\section{Lézervágás előkészítése}

A vágási kísérleteket TruLaser Cell 7020/ Trudisk 4001 berendezésen végeztük $1 \mathrm{~mm}$ vastag horganyzott TRIP 600 acéllemezen. A lézervágási paraméterek az alábbiak voltak:

a) Vágási módszer:

I. módszer: közvetlen vágás beállított para- méterek mellett;

II. módszer: kombinált vágás, gravírozó lézersugárral végrehajtott „felülettisztítás" $\left(\mathrm{O}_{2}-30 \mathrm{~W} ; \mathrm{Ar}, \mathrm{N}_{2}-\right.$ $100 \mathrm{~W})$, majd beállított paraméterek melletti lézervágás;

b) Lézerteljesítmény: $1600 \mathrm{~W}, 1800 \mathrm{~W}$, és $2000 \mathrm{~W}$;

c) Védőgáz: oxigén $\left(\mathrm{O}_{2}\right)$, nitrogén $\left(\mathrm{N}_{2}\right)$ és argon (Ar);

d) Minden vágásnál azonos vágási sebességet $(3 \mathrm{~m} / \mathrm{min})$, védőgáz nyomást $(15$ bar), fókuszpozíciót (-1mm) és hullámhosszt ( $\lambda=1030 \mathrm{~nm}$ ) használtunk, kivéve az $\mathrm{O}_{2}$ segédgázas vágásnál, itt a fókuszpozíció $+1 \mathrm{~mm}$ volt, az égési folyamat végett;

e) A lézervágás szimulációját Tru Tops Cell programmal készítettük el (4. ábra).

A kísérlet során 27 vágást, blokkot, építet-tünk fel, minden müvelet egy új blokk létre- hozását jelentette, a megismételhetőség végett. A lézervágás paramétereit az 1. táblázat tartalmazza. 


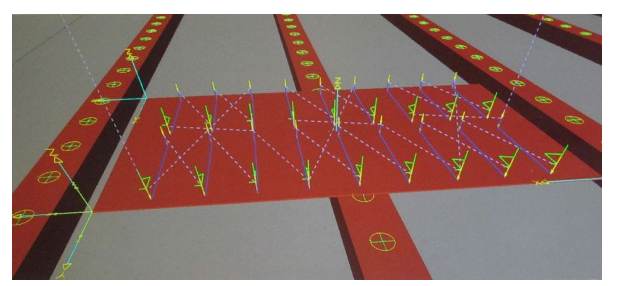

4. ábra CNC lézervágás modellje

1. táblázat. Lézervágási paraméterek

\begin{tabular}{|c|c|c|c|c|}
\hline $\begin{array}{c}\text { Sor- } \\
\text { sz. }\end{array}$ & $\begin{array}{l}\text { Vágás } \\
\text { módja }\end{array}$ & $\begin{array}{l}\text { Vé- } \\
\text { dô- }\end{array}$ & $\begin{array}{l}\text { Teljesít- } \\
\text { mény }\end{array}$ & $\begin{array}{l}\text { Fókusz- } \\
\text { pozíció }\end{array}$ \\
\hline 1 & \multirow{3}{*}{ Közvetlen } & $\mathrm{N}_{2}$ & $1600 \mathrm{~W}$ & -1 \\
\hline 2 & & $\mathrm{~N}_{2}$ & $1800 \mathrm{~W}$ & -1 \\
\hline 3 & & $\mathrm{~N}_{2}$ & $2000 \mathrm{~W}$ & -1 \\
\hline 4 & \multirow{3}{*}{$\begin{array}{c}\text { Kombi- } \\
\text { nált }\end{array}$} & $\mathrm{N}_{2}$ & $1600 \mathrm{~W}$ & -1 \\
\hline 5 & & $\mathrm{~N}_{2}$ & $1800 \mathrm{~W}$ & -1 \\
\hline 6 & & $\mathrm{~N}_{2}$ & $2000 \mathrm{~W}$ & -1 \\
\hline 7 & \multirow{3}{*}{ Közvetlen } & $\mathrm{Ar}$ & $1600 \mathrm{~W}$ & -1 \\
\hline 8 & & $\mathrm{Ar}$ & $1800 \mathrm{~W}$ & -1 \\
\hline 9 & & $\mathrm{Ar}$ & $2000 \mathrm{~W}$ & -1 \\
\hline 10 & \multirow{3}{*}{$\begin{array}{c}\text { Kombi- } \\
\text { nált }\end{array}$} & $\mathrm{Ar}$ & $1600 \mathrm{~W}$ & -1 \\
\hline 11 & & $\mathrm{Ar}$ & $1800 \mathrm{~W}$ & -1 \\
\hline 12 & & $\mathrm{Ar}$ & $2000 \mathrm{~W}$ & -1 \\
\hline 13 & \multirow{3}{*}{ Közvetlen } & $\mathrm{O}_{2}$ & $1600 \mathrm{~W}$ & +1 \\
\hline 14 & & $\mathrm{O}_{2}$ & $1800 \mathrm{~W}$ & +1 \\
\hline 15 & & $\mathrm{O}_{2}$ & $2000 \mathrm{~W}$ & +1 \\
\hline 16 & \multirow{3}{*}{$\begin{array}{c}\text { Kombi- } \\
\text { nált }\end{array}$} & $\mathrm{O}_{2}$ & $1600 \mathrm{~W}$ & +1 \\
\hline 17 & & $\mathrm{O}_{2}$ & $1800 \mathrm{~W}$ & +1 \\
\hline 18 & & $\mathrm{O}_{2}$ & $2000 \mathrm{~W}$ & +1 \\
\hline
\end{tabular}

\section{Eredmények}

A végrehajtott lézervágási kísérletek alapján elmondható, hogy az Ar és $\mathrm{N}_{2}$ munkagázok mellett végrehajtott vágások sikeresek voltak (5. ábra), ugyanakkor az $\mathrm{O}_{2}$ segédgáz alkalmazása nem hozta a várt eredményt, annak ellenére sem, hogy a fókuszpozíciót $+1 \mathrm{~mm}$-re választottuk. $\mathrm{O}_{2}$ gáz alkalmazása esetében a vágás vonala egyenetlen volt (6. ábra), a vágás vonalában fekete elszíneződés, feltehetőn cink- oxid keletkezett, a vágást siker-telennek minősítettük (13 - 18. sorszámú vágások).

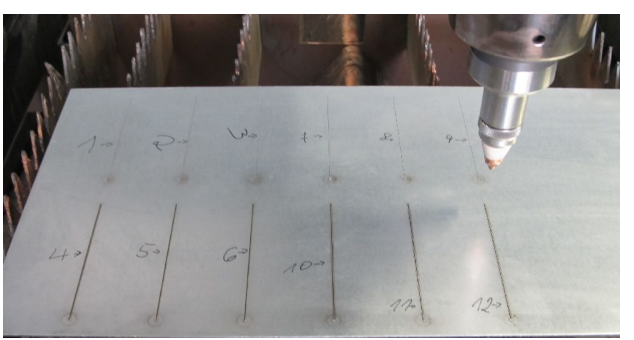

5. ábra CNC lézervágási modell megvalósitása

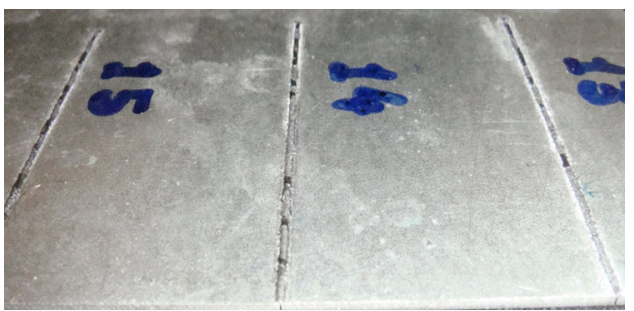

6. ábra. Vágási rés $\mathrm{O}_{2}$ lézervágás után (a lemez hátoldala)

A vágási rés méretét, valamint a hőhatásövezet mikrokeménységét (HV0,2), amelyet Zwick 3212 keménységmérővel mértünk, a 2. táblázat foglalja össze.

2. táblázat. A vágási rés méret ( $\mathrm{mm})$ és a höhatásövezet keménysége $(H V 0,2)$

\begin{tabular}{|c|c|c|c|c|c|}
\hline Sor- & Vágá- & $\mathbf{0}$ & $\mathbf{5}$ & $\mathbf{1 0}$ & $\mathbf{1 5}$ \\
\hline $\mathbf{1}$ & 0,231 & 323 & 198,5 & 176,5 & 164,5 \\
\hline $\mathbf{2}$ & 0,230 & 318,5 & 311 & 229,5 & 176,5 \\
\hline $\mathbf{3}$ & 0,240 & 223 & 243 & 201 & 164,5 \\
\hline $\mathbf{4}$ & 0,230 & 318,5 & 252 & 168 & 178 \\
\hline $\mathbf{5}$ & 0,230 & 303 & 303 & 242 & 125,5 \\
\hline $\mathbf{6}$ & 0,230 & 233 & 164,5 & 164,5 & 139 \\
\hline $\mathbf{7}$ & 0,227 & 277,5 & 207,5 & 176,5 & 159 \\
\hline $\mathbf{8}$ & 0,225 & 242 & 214 & 171 & 159 \\
\hline $\mathbf{9}$ & 0,233 & 217,5 & 243 & 223 & 170 \\
\hline $\mathbf{1 0}$ & 0,237 & 264 & 334 & 277,5 & 178 \\
\hline $\mathbf{1 1}$ & 0,238 & 334 & 232 & 207,5 & 178 \\
\hline $\mathbf{1 2}$ & 0,235 & 264 & 198,5 & 159 & 148 \\
\hline
\end{tabular}

A 2. táblázatból látható, hogy az optimálisnak tekinthető eredmények az Ar munkagázas vágásoknál jöttek létre. A 7. 
ábra a 7., 8. és 9. sorszámú vágás hőhatásövezeti keménységét szemlélteti. A 8. ábra a vágási rés és a lézersugár teljesítmény közti összefüggést mutatja.

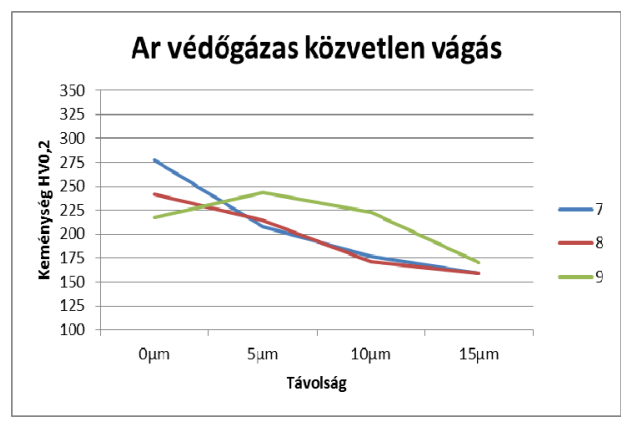

7. ábra. A höhatásövezet keménységének változása (7., 8., 9. sz. vágás)

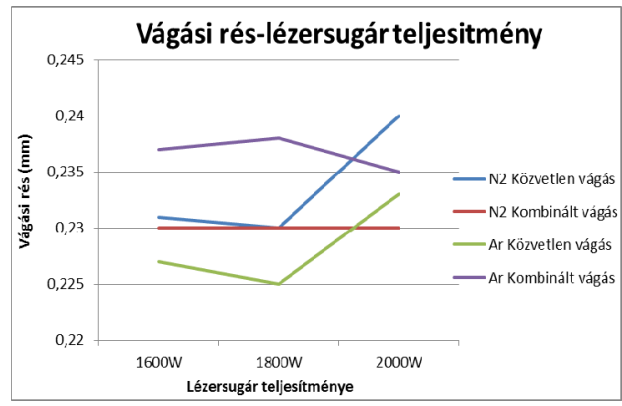

8. ábra. A vágási rés és a lézersugár teljesitmény összefüggése

\section{Következtetések}

A végrehajtott kísérletek alapján az alábbi következtetéseket vonhatjuk le:

1. N2 munkagázas közvetlen vágás: a hőhatásövezet keménységét illetően a 3 . sz. vágás volt az optimális, ugyanakkor a vágási rés mérete szempontjából az 1. és 2. vágás mondható jobbnak.

2. N2 munkagázas kombinált vágás: a vágási rés tekintetében nincs különbség, azonban keménység szempontjából a 6 . kísérleti vágás volt az optimális.

3. Ar munkagázas közvetlen vágás: a keménység és vágási rés szempontjából is a 8. sz. vágás volt az optimális.
4. Ar munkagázas kombinált vágás: a keménységet és vágási rést illetően is a 12 . sz. vágás volt az optimális.

5. Vágási rés - lézersugár teljesítmény alapján a 8 . sz. vágás volt az optimális.

6. A kísérleti eredményekből következik, hogy az oxigén, mint munkagáz nem javasolható az alkalmazott vágási paraméterek mellett.

7. A leghatékonyabb vágás a 8 . sz. vágás volt, amely nem sokban tér el a 6 . sz. vágás eredményétől. A két vágás között a különbség a munkagáz (N2, Ar) és a lézer teljesítménye volt.

8. Az ipari gyakorlat szempontjából elmondható, hogy a nitrogén használata költséghatékonyabb.

\section{Köszönetnyilvánítás}

A szerzők köszönetet mondanak Valenta Lászlónak, az EDUTUS Zrt. vezér-igazgatójának és Farkas Péternek, az EDUTUS Főiskola Lézerlaboratórium igazgatóhelyettesének a lézervágási kísérletek megvalósítását illető támogatásukért. A kutatómunka a TÁMOP 4.2.2D-15/1/ KONV0007 jelü projekt részeként az Európai Unió támogatásával, az Európai Szociális Alap társfinanszírozásával valósult meg.

\section{Szakirodalmi hivatkozások}

[1] Caristan, C. L.: Laser Cutting - Guide for Manufacturing, SME, 2004.

[2] Bitay E.: Lézeres felületkezelés és modellezés, EME kiadó 2007. Kolozsvár pp. 13.

[3] Buza, G.: Lézersugaras technológiák I. TÁMOP-4.1.2.A/2-10/1, Edutus Főisk., Tatabánya, 2012

[4] Tuloki, Sz., Andrews, A., Molnár, L., Vavra, G., Pinke, P., Kovács, C. T.: The effects of the laser cutting's parameters on the mechanical properties on the experimented steel, YPIC 2015, Budapest.

[5] Zsoldos, I.: Különleges autóipari acél ötvözetek, karosszéria elemek lemezanyagai, Korszerü anyagok és technológiák, Széchenyi István Egyetem, Győr, 2013

[6] Lis, A., Dryja, M., Wieczorek, P.: Microstructure Characterization of TRIP Steel CMnAlSi, GSTF Journal of Engineering Technology (JET), Vol. 2, No. 3, dec. 2013 